\title{
How is Picture Mnemonic Implemented in Teaching English Vocabulary to Students with Intellectual Disability?
}

\author{
$1^{\text {st }}$ Diah Kurniati \\ English Language Education \\ Universitas Negeri Semarang \\ Semarang, Indonesia \\ diah.kurniati@umk.ac.id \\ $4^{\text {th }}$ Dwi Anggani Linggar Bharati \\ English Language Education \\ Universitas Negeri Semarang \\ Semarang, Indonesia \\ dwianggani@yahoo.com
}

\author{
$2^{\text {nd }}$ Dwi Rukmini \\ English Language Education \\ Universitas Negeri Semarang \\ Semarang, Indonesia \\ wiwidwirukmini@yahoo.com
}

\author{
$3^{\text {rd }}$ Mursid Saleh \\ English Language Education \\ Universitas Negeri Semarang \\ Semarang, Indonesia \\ mursids@hotmail.com
}

\begin{abstract}
It is challenging for most teachers to teach English to students with intellectual disability. One of the reasons is because English is considered as a difficult subject especially for foreign language students, including students with intellectual disability. Furthermore, it is because students with intellectual disability have special characteristics which may become obstacles during teaching learning process. Intellectually disabled students tend to have a lack of motivation, low memory ability, to be passive, be easily distracted, and have problems in language development as well. Therefore, an appropriate strategy or device which can improve attention and increase students' ability to remember should be implemented. One of the strategy is the use of picture mnemonic. This research aims to describe how the picture mnemonic is implemented in teaching English vocabulary to the eighth grade secondary students with intellectual disability. The method used in this research was descriptive qualitative. The participants were the English teacher and 12 eighth grade secondary students with intellectual disability at State Special School (SLB N) Purwosari Kudus Indonesia. The observation sheet was used to get the data related to the implementation of picture mnemonics focusing on two aspects: teaching presentation and students' behavior. The results of this research showed that in general, the implementation of picture mnemonics for teaching English vocabulary was in very good criteria with the average score was 3.69. Related to the teaching presentation aspect, the principles of picture mnemonics implementation had been successfully fulfilled by the teacher, such as presentation, association and retrieval. It was also found that there was improvement on students' vocabulary retention. Moreover, dealing with students' behavior aspect, during the implementation of the picture mnemonics the students were active, involved and enjoyed the teaching learning process. Considering the benefits of using picture mnemonics, it is suggested to use these picture mnemonics especially when teaching students with disability.
\end{abstract}

Keywords - picture mnemonic, students with intellectual disability, English vocabulary

\section{INTRODUCTION}

It is challenging for most teachers to teach English to students with intellectual disability. One of the reasons is because English is considered as a difficult subject especially for foreign language students, including students with intellectual disability. Furthermore, it is because students with intellectual disability have special characteristics which may become obstacles during teaching learning process. Intellectually disabled students tend to have aa lack of motivation, low memory ability, to be passive, be easily distracted, and have problems in language development as well.

The problem when teaching English to students with intellectual disability is also experienced by the English teacher at State Special School (SLB N) Purwosari Kudus, Central Java Province, Indonesia. She said that one of the obstacles appeared when teaching the students was related to the memory matter. In detailed explanation, the students have difficulties when they have to remember what they have learned. The learning and memory capabilities of people with intellectual disabilities are significantly below average in comparison to peers without disabilities [1]. Moreover, people with intellectual disabilities develop learning sets at a slower pace than peers without disabilities, and they are deficient in relating information to new situations [2]. Another problem is related to the attitudes and behavior of the students with disabilities such as tend to be passive, uninvolved and unmotivated in joining the class. It is also mentioned that students with disabilities usually have a bad attitude toward learning and they need to be handled with care [3]. Furthermore, they 
are more likely to develop negative attitudes toward learning and behavior misconduct in classroom [4].

Considering the students' difficulties in remembering what they have learned and their lack of motivation in joining teaching learning process, an appropriate strategy should be used in order to increase students' ability to remember including strategies to improve attention and to increase meaningful learning, especially in learning vocabulary. One of the strategies is by using mnemonics. Mnemonic strategy is defined as systematic procedures for intensification of memory [5]. The idea of mnemonics is application in developing better ways to take in (encode) information, so that it is much easier to remember (retrieve) it.

The use of mnemonic strategies has been conducted by researchers either for teaching science or social subject or in language learning and they have been proven to be extremely effective in helping people to remember things. Studies on the use of mnemonics related to vocabulary learning for regular students have also been done many researchers. One of the findings of the studies was that the keyword method can be considered as a further vocabulary instruction to develop secondary students' vocabulary because of the effectiveness of the method [6]. Another study which was done on the role of mnemonic strategy and context method on vocabulary retention found that the group instructed by mnemonic strategy was more successful than the group instructed by context technique [7]. In addition, Phillips [8] in his research also found that visual strategies (word pairing and semantic mapping strategies helped regular participants to learn vocabulary. Finally, P. Fasih, S. Izadpanah, and A. Shahnavas [9] who studied on the effect of mnemonic instruction on content vocabulary learning of students claimed that mnemonic vocabulary instruction increased students' engagement and motivation toward vocabulary learning.

Mnemonic strategies have also a positive effect in the application of learning the English vocabulary for students with disability. Reference [10] who measured the effectiveness of pictured mnemonic strategy in learning similar English language letters among 90 students with learning disabilities in Saudi Arabia by using pretest, posttest and follow up test found out that there were significant differences attributed to the teaching method, in favor of the method of both modified and abstract letters, while there was no statistically significant differences due to gender or interaction between the teaching method and gender. Research on the use of mnemonics on vocabulary acquisition and retention of high school students with learning disabilities was also conducted by Whitescarver [11]. He found that the use of mnemonic devices increased the acquisition and retention of vocabulary. Moreover, the students also showed a satisfactory rating in ease and enjoyment of using mnemonics.

Although many researchers have conducted research related to the use of mnemonics, however, as far as we know, research which investigates the implementation process of mnemonics especially picture mnemonics for teaching English to students with intellectual disability is rarely done. In addition, those previous studies mostly focused on the improvement of English achievement in the use of mnemonics. None of those studies paid attention on investigating the process of how the mnemonic strategies are implemented in language learning. Therefore, we are interested in conducting a study entitled "How is picture mnemonics Implemented in Teaching English Vocabulary to the Eighth Grade Students with Intellectual Disability at State Special School (SLB N), Purwosari Kudus, Indonesia? The objective of the study is to describe the implementation process of picture mnemonics in teaching English vocabulary to students with intellectual disability.

The research problem of this paper is "How is picture mnemonics Implemented in Teaching English Vocabulary to the Eighth Grade Students with Intellectual Disability at State Special School (SLB N), Purwosari Kudus, Indonesia? Therefore, the objective of the study is to describe the implementation process of picture mnemonics in teaching English vocabulary to students with intellectual disability.

Mnemonic means "aiding the memory" [12]. It is derived from the Greek word Mnemosyne, referring to the ancient Greek goddess of memory. Mnemonic is a memory enhancing instructional strategy that involves teaching students to link new information taught to information they already know [13]. A mnemonic is also defined as any procedure designed to improve one's memory [14]. Similarly, Bakken [15] pointed out that mnemonic strategies are systematic procedures for enhancing the memory and making information more meaningful. Furthermore, he explained that mnemonic instruction is a way to help students with intellectual disabilities remember new information more effectively, efficiently, and easily.

Mnemonic strategies are divided into five classes [16]. They are linguistics, spatial, visual, physical response and verbal methods. However, in this present study, the writers only focus on picture mnemonics as one of the type of visual mnemonic classification which make use of pictures or visualizations to create an association to the target concepts (e.g., symbolic, pictographic).

Thompson in [13] explained that when using picture visual mnemonic, the target words are associated (paired) with pictures instead of associating the words with their definition or translation. Pairing pictures with words in L2 results in better recall than pairing them with their L1 equivalents. Moreover, Gains \& Redman [17] believed that objects and pictures can facilitate recall. Finally, pictures and objects not only can be used to give meaning and information but they can also be used to the motivation and interest of the students [13]. By using picture visual mnemonics, the meaning of the word becomes clear.

\section{METHOD}

This research used descriptive qualitative method which described the investigation results on the implementation process of picture mnemonics for teaching English vocabulary to students with intellectual disability which focused on the teaching presentation and the students' behavior aspects. This research was conducted at State Special School (SLB N) Purwosari Kudus which is located 
at Jl. Ganesha II No. 32 Purwosari Kudus, Central Java Province, Indonesia. The total number of students are 184 students, 96 boys and 88 girls. The subjects of this research were the English teacher at State Special School (SLB N) Purwosari Kudus and the eighth grade students with intellectual disability. The number of students were twelve, eight boys and four girls.

The data collecting technique used in this research was observation. The writers used observation guideline (check list) as the instrument to get deeper understanding about the implementation process of picture mnemonics. The observation guideline consists of two aspects to be observed, they were teaching presentation in order to know how the picture mnemonics were implemented and students' behavior during the implementation of picture mnemonics. Each aspect consists of several variables. The writers did six observations in one and a half month. The writers used a Scale ranging from one point for "bad," two points for "fair," three points for "good," and four points for "very good". When the writers did observation, there were 4 topics taught to the students: Fruits, Numbers, Food and Drinks. During the implementation of picture mnemonics, picture of fruits, numbers, food and drinks in $15 \mathrm{~cm} \times 23 \mathrm{~cm}$ were used by the teacher.

In analyzing the data, the writers did several steps. First of all, putting the observation score (observation $1-6$ ) of each indicator or variable for all aspects as follows:

TABLE 1. EXAMPLE OF OBSERVATION RESULTS OF PICTURE MNEMONIC IMPLEMENTATION

\begin{tabular}{|c|c|c|c|c|c|c|c|c|}
\hline \multirow{2}{*}{ No } & \multirow{2}{*}{ Aspects } & \multirow{2}{*}{ Indicators } & \multicolumn{6}{|c|}{ Observation } \\
\hline & & & 1 & 2 & 3 & 4 & 5 & 6 \\
\hline 1 & $\begin{array}{c}\text { Teaching } \\
\text { Presentation }\end{array}$ & $\begin{array}{l}\text { 1. The class material was } \\
\text { explained in an } \\
\begin{array}{lr}\text { understandable } \\
\text { using }\end{array} \\
\begin{array}{l}\text { mnemonics } \\
\text { picture }\end{array} \\
\end{array}$ & 4 & 4 & 4 & 4 & 4 & 4 \\
\hline
\end{tabular}

Then, the writers calculated the average score of indicators or variables of each aspect. After that determining the average score of all aspect was done by the writers. Next, the writers interpreted the average score with the interval criteria. Finally, the writers conclude. The interval criteria are as follows:

TABLE 2. INTERVAL CRITERIA

\begin{tabular}{|c|c|c|}
\hline No & Score & Criteria \\
\hline 1. & $1-1.75$ & $\mathrm{Bad}$ \\
\hline 2. & $1.76-2.31$ & Fair \\
\hline 3. & $2.32-3.17$ & Good \\
\hline 4. & $3.18-4.00$ & Very Good \\
\hline
\end{tabular}

III. FINDINGS AND DISCUSSION

Based on the data analysis, the writers found that in general, the implementation of picture mnemonics for teaching English vocabulary to the eighth grade secondary students with intellectual disability at State Special School (SLB N) Purwosari Kudus was in very good criteria with the average score 3.69. The details of the findings can be seen in the following table.

TABLE. 3 THE SUMMARY OF OBSERVATION RESULT OF PICTURE MNEMONIC IMPLEMENTATION PROCESS FOR TEACHING BASIC ENGLISH COMMUNICATION FOR INTELLECTUALLY DISABLED STUDENTS

\begin{tabular}{|c|c|c|c|c|c|c|c|c|c|}
\hline \multirow{2}{*}{ No } & \multirow{2}{*}{ Aspects } & \multicolumn{6}{|c|}{ Observation Result } & Average & Criteria \\
\cline { 3 - 9 } & 1 & 2 & 3 & 4 & 5 & 6 & & \\
\hline 1 & $\begin{array}{c}\text { Teaching } \\
\text { Presentation }\end{array}$ & 3.31 & 3.54 & 3.69 & 3.69 & 3.69 & 3.77 & 3.62 & VG \\
\hline 2 & Students' behavior & 3 & 3.50 & 4 & 4 & 4 & 4 & 3.75 & VG \\
\hline & Average & 3.16 & 3.52 & 3.85 & 3.85 & 3.85 & 3.89 & 3.69 & VG \\
\hline & Criteria & $\mathrm{G}$ & $\mathrm{VG}$ & $\mathrm{VG}$ & $\mathrm{VG}$ & $\mathrm{VG}$ & $\mathrm{VG}$ & $\mathrm{VG}$ & \\
\hline
\end{tabular}

Note: $\mathrm{G}=$ Good, $\mathrm{VG}=$ Very Good

Based on the table above, it can be concluded that the observation results of teaching presentation were 3.62 and students' behavior was 3.75 . Both of them were categorized as very good criteria.

Dealing with teaching presentation aspect, during the teaching learning process, the teacher had successfully fulfilled the principles of implementing the mnemonic strategy, such as, presentation/indicator 1 (The teacher presented the material in an understandable way.), association/indicator 2 (In the implementation of picture mnemonic, the teacher associated the vocabulary learned with picture mnemonics) and retrieval/indicator 10 (In the implementation of picture mnemonics, the teacher retrieved the material that has been taught). Those three indicators were scored 4 in observation 1 up to observation 6 .

It was found out that when teaching vocabulary to the students, the teacher associated the target vocabulary (Fruits, Numbers, Food and Drinks) with picture instead of pairing them with Indonesian version. Using association with picture mnemonics in six times, make the students' memorization were improved. It can be seen when the teacher retrieved the material that had been learned, $75 \%$ of the students could remember those words. These findings support the research conducted by Whitescarver [11] who found that the use of mnemonic devices increased the acquisition and retention of vocabulary.

The indicator which got the lowest score (1) which was categorized as a bad category was indicator 9 , that was the teacher answered questions carefully and satisfactorily in the implementation of picture mnemonics. During the observation 1 up to 5 , none of the students asked question, but in the observation 6 when teaching about Drinks, one of 
the students, Sanjaya asked a question about the translation of telor ceplok in English.

Finally, as stated preciously that dealing with the students' behavior aspect, the score was 3.69 which was also categorized as a very good criterion. This second aspect was related to the students' activeness, interest and involvement. It also related to the feeling of enjoyment and relaxation during learning English vocabulary using picture mnemonics. Previously, the students tend to be passive, uninvolved, and unmotivated in joining the English class, but after the implementation of picture mnemonics, they were involved, motivated and enjoyed the teaching learning process. It may because students with disability tend to be attracted by pictures in teaching learning process. It approves what has been found in [18] that mnemonic technique does not only help students in terms of long term retention, but it also provides motivation for future learning as much as creating a joyful classroom environment and attract the motivation and interest of the students [13].

\section{CONCLUSIONS}

Based on the findings, the writers conclude that in general, the implementation of picture mnemonics in teaching English vocabulary to the eighth secondary students with intellectual disability at State Special School Purwosari Kudus, Central Java Province, Indonesia was in very good criteria with 3.69 score. Related to the teaching presentation aspect, the principles of picture mnemonics implementation had been successfully fulfilled by the teacher, such as presentation, association and retrieval. It was also found that there was improvement on students' vocabulary retention. Moreover, dealing with students' behavior aspect, during the implementation of the picture mnemonics the students were active, involved and enjoyed the teaching learning process. Considering the benefits of using picture mnemonics, it is suggested to use these picture mnemonics especially when teaching students with disability.

\section{REFERENCES}

[1] A. Shree and P. C. Shukla, "Intellectual Disability: definition, classification, causes and characteristics", Learning Community: 7 (1), April 2016, DOI: 10.5958/2231-458X.2016.00002.6

[2] M. B. Smith, J. R. Patton, and S. H. Kim, Mental retardation (7th ed.), Upper Saddle River, NJ: Pearson Education, 2006.

[3] D. F. Bradley, J. A. Pauley and J. F. Pauley, Effective Classroom Management: Six Keys to Success, Rowman \& Littlefield Publishing Group, 4501 Forbes Blvd., Suite 200, Lanham, MD 2076, 2006.
[4] J. McCaskey, "Elemantary School Teachers'Level of Concern with Disruptive Student Behaviors in the Classroom", Ph.D. dissertation, Walden University, 2015.

[5] K. Jurowski, A. Jurowska, M. Krzeczkowska, "Comprehensive Review of Mnemonic Devices and Their Applications: State of the Art". Internstional E-Journal of Science, Medicine \& Education, Vol. 9, Issue 3, p. 4, November 2015.

[6] C. Benge, and M. E. Robbins, "Using keyword mnemonics to develop secondary students' vocabularies: A teacher's action research", Journal of Language and Literacy Education, 6(1), 93104, 2009.

[7] A. Saricoban, and N. Basibeck, "Mnemonic Technique Versus Context Method in Teaching Vocabulary at Upper-Intermediate Level," Egitim ve Bilim, 37(164), 25, 2012.

[8] M. Phillips, "The effects of visual vocabulary strategies on vocabulary knowledge," M.S. thesis, Marshall University, Huntington, WV, 2016.

[9] P. Fasih, S. Izadpanah, and A. Shahnavas, "The Effect of Mnemonic Vocabulary Instruction on Content Vocabulary of Students," Journal of Language and Education, 4(1), 42-62., 2018, doi:10.17323/2411-7390-2018-4-1-42-62

[10] M. A. Dakhiel, and M. O. A. Al Rub, "The Effectiveness of Pictured Letter Mnemonic Strategy in Learning Similar English Language Letters among Students with Learning Disabilities," World Journal of Education.7(6), November 2017, doi:10.5430/wje.v7n6p21.

[11] E. L. Whitescarver, "Effect of Mnemonics on the Vocabulary Acquisition and Retention of High School Students with Learning Disabilities," Ph.D dissertation, 2018, Available: https://rdw.rowan.edu/etd/2567.

[12] K. L. Higbee, "Recent Research on Visual Mnemonics: Historical Roots and Educational Fruits. Review of Educational Research," Fall, 49(4), Pp. 611-629, 1979.

[13] M. Amiryousefi, and S. Ketabi, "Mnemonic Instruction: A Way to Boost Vocabulary Learning and Recall", Journal of Language Teaching and Research, 2(1), pp.178-182, February 2011, doi $: 10.4304 /$ jltr.2.1.178-182

[14] T. E. Scruggs, M. A. Mastropieri, S. L. Barkeley, and L. Marshak, "Mnemonic Strategies: Evidence-based practice and practice-based evidence," Intervention in School and Clinic, 46 (2), 79-86, November 2010, doi: 10.1177/1053451210374985

[15] J. P. Bakken, "Mnemonic Strategies: Helping Students with Intellectual and Developmental Disabilities Remember Important Information," Global Journal of Intellectual and Developmental Disabilities. 2(3):555587, July 2017.

[16] Thompson,I, "Memory in Language Learning. in Learner Strategies in Language Learning," A.Wenden, \&J.Rubin (Eds), New Jersey:Prentice-Hall, 1987, pp 43-56.

[17] R. Gains and S. Redman, "Working with Words: A Guide to Teaching and Learning Vocabulary," Cambridge: Cambridge University Press, 1986

[18] M. Kayaalti, "Mnemonic technique- An Effective Vocabulary Teaching Method to Plurilingual Students," Modern Journal of Language Teaching Methods (MJLTM), ISSN:22516204.www.mjltm.org, August 2018. 